\title{
Lost in implementation? REDD+ country readiness experiences in Indonesia and
} Vietnam

Casse, Thorkil; Milhøj, Anders; Nielsen, Martin Reinhardt; Meilby, Henrik; Rochmayanto, Yanto

\section{Published in:}

Climate and Development

DOI:

$10.1080 / 17565529.2018 .1562870$

Publication date:

2019

Document version

Peer reviewed version

Citation for published version (APA):

Casse, T., Milhøj, A., Nielsen, M. R., Meilby, H., \& Rochmayanto, Y. (2019). Lost in implementation? REDD+ country readiness experiences in Indonesia and Vietnam. Climate and Development, 11(9), 799-811. https://doi.org/10.1080/17565529.2018.1562870 


\section{Lost in implementation? REDD+ country readiness experiences in Indonesia and}

Vietnam

Thorkil Casse, Roskilde University

Martin Reinhardt Nielsen, Copenhagen University

Henrik Meilby, Copenhagen University

Anders Milhøj, Copenhagen University

Yanto Rochmayanto, Bogor University

Abstract:

The REDD+ readiness phase leading up to implementation has been slow and has fallen short of expectations. In this article, we present REDD+ experiences from Indonesia and Vietnam with a focus on the readiness phase, examining policy processes at the central, provincial and local levels. Interviews with key stakeholders (officials, donors, NGOs, village representatives) and data from household surveys suggest that efforts have been concentrated at the central level, with the provincial level mainly feeding data into the process and the local level practically left to its own devices. Furthermore, the REDD+ design may be misguided as it exempts the major stakeholders, namely the state and private enterprises, from declaring emissions sub-targets in the national carbon reduction action plans, and focuses exclusively on rural forest dwellers who struggle to understand the ideas that underpin REDD+.

Keywords: REDD+, environmental governance, stakeholders, tree cover 


\section{Introduction}

For several years, REDD+ (Reduction of Emissions from Deforestation and Degradation) was considered a supplementary measure at the COP (Conference of Parties) meetings, but it is now regarded as a major mitigation instrument in global climate change policies, having worked its way into the final document at the COP 21 meeting in Paris (UNFCC, 2015 Deforestation and forest degradation account for an estimated 15\% of global anthropogenic $\mathrm{CO}_{2}$ emissions, although estimates vary greatly due to uncertain $\mathrm{FAO}$ estimates of global deforestation rates (van der Werf et al., 2009; Baccini et al., 2012). The original idea to create a facility to reduce carbon emissions through compensation for reducing deforestation rates came from low-income countries (Financial Times, 2005). Other mitigation measures, like energy-saving investments, are clearly required in both of these countries. But here we focus on REDD+ implementation, and specifically on the readiness phase.

Starting in 2007/2008, the Parties or countries voluntarily undertook programs to reduce emissions from deforestation. Successive COP meetings employed the word 'encourage' when addressing REDD+ (see for example UNFCC, 2011), but in the 2015 Paris agreement the wording changed to 'Parties should take action'. The Paris agreement urged developed countries to finance both mitigation and adaptation strategies in developing countries to the tune of USD 100 billion annually (UNFCC, 2015).

REDD+ is a mechanism that commits developed and developing countries to reducing carbon emissions, as discussed at international level in COP meetings (Brockhaus et al., 2014; Matthews et al., 2014). Global governance frames the conditions for all REDD+ countries, but the achievement of REDD+ goals requires the formulation of carbon reduction-inducing policies at the national level.

The UN and the World Bank are responsible for the most comprehensive programs, from policy framing to local activities, and they are the most significant organizations through which donor funds are channelled.Norway stands out as the leading donor, together with the USA and Germany, with these countries providing approximately $\$ 1$ billion each out of a total REDD+ financial envelope of approximately $\$ 10$ billion (Norman \& Nakhooda 2014/2015). Countries have used these funds for the preparation of REDD+ (i.e. the readiness phase). However, no country has yet reached this stage, with Vietnam being a possible exception (see discussion later on

In 2008, the UN-REDD program prepared a framework document for six REDD+ pilot countries, which outlined a time frame of 18 months from the availability of donor payments until entry into the international carbon market (UN-REDD, 2008). The World Bank designed a funding window called the Forest Carbon Partnership Facility (FCPF), and its first annual report concluded that the first year was one of 'tremendous 
progress', since the number of REDD+ program countries increased from 14 to 37 (FCPF, 2009: 1). In 2016, the most notable achievement was that Costa Rica and the Democratic Republic of Congo succeeded in moving to the implementation phase (FCPF, 2016a). Importantly, the UN-REDD measured the success of REDD+ in the partner countries according to the completion of reports on national forest inventories, action plans and reference emission levels, and not actual REDD+ activities on the ground (UN-REDD, 2015a).

We evaluate the REDD+ political process by studying the readiness phase in Indonesia and Vietnam through the activities of the two main programs. Vietnam was among the original 14 REDD+ countries both within the UN and the WB framework (Forest Carbon Partnership Facility (FCPF), 2009), and during the first years of REDD+ until 2015, both organizations heralded Vietnam as a genuine success story (FCPF, 2009, UN-REDD, 2015b and FCPF, 2015). Since 2016, however, there has been less publicity about progress in Vietnam. Indonesia has received $19 \%$ of total pledged or allocated global REDD+ funding from donors (Norman M. \& Nakhooda S. (2014/2015), p. 23). Indonesia is a crucial country in the REDD+ framework because of its forest size, and FCPF annual reports document reforms of decentralization and the 'One Map Policy' (FCPF 2015, 2016a). We will return to the 'One Map Policy' later.

This paperaims to analyzes REDD+ performance in Indonesia and Vietnam from 2010-2017 and discusses the extent to which REDD+ efforts have stabilized or reduced deforestation rates in case study areas and/or achieved the overall objectives of the REDD+ program. So far, the REDD+ readiness phase lacks clear objectives, and we therefore propose a new evaluation framework, which we consider a suitable basis for policy development analyses. The paper examines the core REDD+ elements and asks whether the two governments have taken steps to apply them in drafting new forest policies (see below, including table 2).

The readiness phase objectives for Indonesia and Vietnam differ slightly in wording, but are largely similar in substance, both in terms of policies and outputs. In Indonesia, objectives have focused on strengthening institutional goals: 'setting up national readiness management arrangements' (FCPF, 2016a) or 'strengthen[ing] multi-stakeholder participation and successful demonstration of establishing an REL (Reference Emission Level), MRV (Monitoring, Reporting and Verification) and a fair payment system' (UNREDD, 2009:6). In Vietnam, 'the objective is to support Vietnam to become ready for future REDD+ implementation' (FCPF, 2016b) or 'to enhance Vietnam's ability to benefit from future results-based payments for REDD+ and undertake transformational changes in the forestry sector' (UN-REDD, 2013:11). The formulation of goals and expected outcomes was more specific for Indonesia than for Vietnam, where documents mainly addressed outcomes. 
Financial, social and institutional barriers often constitute the direct causes of shortcomings in policy implementation. Here, we confine our analysis to assessing tangible outputs of the readiness phase or lack thereof. As evident in the literature, scholars face challenges in their attempts to define success when it comes to the REDD+ readiness phase. Svarstad and Benjaminsen (2017) claim that organizations are concerned with marketing success narratives, even though the gaps between claims and evidence are apparent. Other authors list criteria to achieve success, such as the formation of coalitions to promote a new agenda (Brockhaus et al. 2014), the creation of appropriate incentives (Streck, 2012) or the establishment of government super-bodies (Purnomo et al., 2012).

\section{REDD+ expectations}

No recipes or standards - not to mention concrete results - are available to gauge the success of REDD+ policy outcomes. We argue that most REDD+ literature addresses only a single aspect, e.g. monitoring issues or the formulation of a benefit-sharing mechanism, and therefore misses the bigger picture, i.e. the national performance of REDD+ programs. A notable exception to this is Matthews et al. (2014) who concentrate on potential policy instruments and the quantification of impacts, whereas we contemplate the links between the national, provincial and local levels in two countries.

In the readiness phase, we expect countries to define the core REDD+ elements: 1) identify the main deforestation drivers, 2) determine the REL (Reference Level, base year carbon emissions), 3) develop and implement MRV (Monitoring, Reporting and Valuation) procedures, 4) engage in multi-actor negotiations, 5) develop and implement benefit-sharing schemes, and 6) ratify and adhere to social safeguards. We consider the core REDD+ elements necessary to reach the implementation phase.

In the implementation phase, reduction of deforestation will occur if the core REDD+ elements are defined in operational terms and implemented. We selected these core REDD+ design elements based on readings of REDD+ global reports (UN-REDD, 2010 and FCPF, 2016).

\section{Theory: Environmental governance}

From the late 1980s onwards, the failure of state-controlled international regimes in the environmental management of natural resources (declining fish stocks, ocean acidification, species extinction and climate change, see Walker et al., 2009) prompted a new international approach, namely the introduction of global governance and the joint development of required instruments and mechanisms. Increasingly, NGOs and multinational actors participated in meetings and influenced global decisions (Lemos and Agrawal, 2006). A crucial argument for promoting such global solutions is the need to address transboundary environmental issues like climate change. States often do not have sufficient resources and capacity to address such issues 
alone, and therefore reach out to communities or international institutions to find solutions at the appropriate scale. Recent resentment from the US regarding the non-binding Paris agreement on carbon emission targets demonstrates the problem of national sovereignty versus multilateral, scientific, and more reliable 'imposed' goals. The slow and not yet confirmed shift away from state-controlled environmental management to market-based instruments, ecotaxes, voluntary agreements and subsidies, preceded the global embrace of carbon credit trading, which is partly linked to the CDM (Clean Development Mechanism) in developing countries. Initially, it was thought that once REDD+ reached the implementation phase, it would be partly funded by the private sector (FCPF, 2011).

The main weakness in global environmental governance is the absence of adequate instruments for putting multilateral agreements into action (i.e. there are no sanctions for non-compliance and no guarantee of compensation). Multi-stakeholder partnerships are failing to live up to their promises (Pattberg and Widerberg, 2015). Often, transnational arrangements do not measure environmental goals as such, but instead use voluntarily disclosed information as a proxy for effectiveness. The Forest Stewardship Council, the Carbon Disclosure Project and the C40 Cities Climate Leadership are examples of information serving as a project end goal, according to Pattberg and Widerberg (2015). Multi-stakeholder governance may not close the legitimacy gap in the eyes of civil society if the government ignores public concerns, and the inclusion of more partners (private sector, NGOs) does not automatically lead to greater effectiveness. The overall objective in multi-stakeholder arrangements becomes a choice between accommodating participatory and social legitimacy concerns or leaning towards a display of effectiveness with a firm focus on ecological or economic goals, thereby becoming less participatory (Taylor and Cheng, 2012). These authors suggest including an embeddedness approach, such that success or failure are judged using alternative criteria such as the contribution to human regional development or the environment.

After evaluating 150+ projects executed by the World Bank, Buntaine and Parks (2013) formulated, amongst others, two hypotheses pertinent to our analysis: 1) The more global the objectives (such as "reducing climate change" or "protecting biodiversity"), the less likely it is that positive outcomes will result. 2) Projects with a greater emphasis on environmental funding compared to development objectives generally achieve poorer results. In the statistical test, only the first hypothesis proved significant and was thus accepted.

REDD+ fits into this category of donor-driven projects with very broad and global objectives. Miller (2014) suggests that large countries hosting important biodiversity resources are likely to accept global projects only if they are coupled to additional funding for development purposes: 


\subsection{Environmental governance and REDD+}

A review of scholarly work reveals how debates about REDD+, global environmental governance and the scope of these initiatives have changed over time. Caplow et al. (2011) reviewed projects aimed at achieving carbon emissions reductions that were introduced before REDD+ was conceived. Most of the projects lacked baseline data and general rigour in terms of objectives and monitoring tools. Caplow et al. were specifically concerned about the absence of counterfactuals for impact evaluation in these projects. At the beginning of the REDD+ readiness period, more observers were optimistic about the potential outcomes. Observers initially concluded that international civil society, businesses and local communities were concerned about forest rights and investment security, and that this increased the odds of ending up with good governance and REDD+ legitimacy (Lederer, 2011). Moreover, REDD+ strategies were seen as potentially able to combine the mitigation of carbon emissions, poverty reduction for millions of poor people, and the promotion of biodiversity conservation (Hayes and Persha, 2010).

A couple of years later, the optimism had slowly begun to evaporate, and today observers tend to underline the challenges inherent in REDD+. Concerns have emerged about how to specify the drivers of deforestation, define forest services, and reach a better understanding of existing benefit-sharing schemes such as Payment for Ecosystem Services (Matthews et al. 2014). Without a proper actor analysis at the national level that includes the agents responsible for deforestation, carbon emission reductions are unlikely to materialize (Brockhaus et al., 2014). A global-national-local focus, rather than an emphasis on international REDD+ debates alone, will facilitate what the authors call the 'institutionalization of discourse for transformational change'. For example, a performance-based economic mechanism at the national level might turn out to be inapplicable at the provincial or local level, where preferences for fair distribution predominate (Matthews et al., 2014). In a survey covering seven REDD+ countries, policy makers, business managers and NGOs answered questions about REDD+ objectives, monitoring and funding options. The results indicated that REDD+ strategies could converge towards the carbonization of forest (disregarding safeguards and biodiversity benefits), technicalization and centralization of the process (Vijge et al., 2016). Finally, the question of marketization favouring a higher degree of private sector involvement remains unsolved, due to uncertainties about whether the private sector will show an interest in REDD+. Furthermore, lack of good governance and administrative capacity could neutralize any achievements in the establishment of a wellfunctioning MRV system (Ochieng et al., 2016). REDD+ programs furthermore fall short in terms of addressing the drivers of deforestation; training courses in REDD+ countries are ad hoc and of poor quality; and little attention is paid to making REDD+ functional at the subnational level (Minang et al., 2014). 
Scholars have examined the REDD+ process in Peru in several papers which served as additional inspiration for our approach. Robiglio et al. (2014) assess the political process and argue that shortcomings exist in areas of cross-sectoral stakeholder dialogue, limited understanding of deforestation drivers, and lack of integration of REDD+ policies in national and regional plans. The two first shortcomings are similar to observations we made in Indonesia and Vietnam, and add to the impression that the REDD+ design is often difficult to implement to the letter. White (2014) contrasts two approaches in the indigenous people's rights guarantee in the REDD+ framework, namely a safeguard-based REDD+ perspective and a rights-based approach underlining local control of all forest goods and services. If the land tenure conflicts were solved, illegal use of forest resources would decrease. Land tenure conflicts are common in our two countries of study.

\section{Methods and data}

We consulted government officials at national, province, district and commune levels, as well as donors and NGOs working with REDD+ activities in Indonesia (Jakarta and Berau in eastern Kalimantan) and in Vietnam (Hanoi, Lam Dong and Lao Cai provinces). Conducting research in Vietnam requires that official introduction meetings are first conducted at all administrative levels of the People's Committee, and at the central level in this case the Ministry of Agriculture and Rural Development (MARD) in Hanoi. In the People's Committee meetings, approximately 10-15 officials participated, though only 2-3 of them expressed their views. In Indonesia, rules are less strict but official visits added to our qualitative understanding of the REDD+ framework in this country. Our objective was to obtain diverse perspectives about the REDD+ framework in both countries. In Indonesia we visited two ministries, two embassies, FCPF, CIFOR, a research institution, and the WWF (an international NGO). At the provincial level, we held meetings with the forest service, the provincial council on climate change, and the University of Tanjung Para. At the district level, we met with the forest service, the district REDD+ secretariat, TNC (The Nature Conservancy), three Indonesian NGOs, and GIZ. In Vietnam, meetings were held with one ministry, several NGOs (international and Vietnamese), two embassies, JICA, a USAID-supported program, UN-REDD, FCPF, and two universities. At the provincial and district levels we visited the People's Committee, and the commune level we met with village leaders. Our discussions with these informants raised questions about stakeholders' understanding of, and perceptions about, progress in REDD+ activities orchestrated primarily by the UN-REDD and the World Bank.

Authorities both in Indonesia and Vietnam assisted us in selecting provinces and districts where the UN-REDD and World Bank FCPF are pursuing preliminary REDD+ activities. In Indonesia, we visited the province of 
eastern Kalimantan, Berau district (four villages). TNC (The Nature Conservancy) and the District Government oversee the REDD+ programmes with the clear aim of involving FCPF at least in the benefit-sharing schemes. However, the benefit-sharing project never materialized. In collaboration with Bogor Agricultural University, we selected the study villages. In Vietnam, we collected data in central Vietnam (Lam Dong province, one village in each of three districts) and North Vietnam (Lao Cai province, one village in each of three districts). In Indonesia, all REDD+ activities are now concentrated on the island of Kalimantan, mostly in eastern Kalimantan. In Vietnam, Lam Dong belongs to the first round of REDD+ provinces, and Lao Cai to the second round. In collaboration with Hanoi Agricultural University in the case of Lao Cai, and UN-REDD office in Da Lat (Lam Dong), we selected the districts/villages in Lam Dong and Lao Cai.

Figure 1 shows the location of the sites and Table 1 shows the number of households in the survey. They are all REDD+ sites. Approximately $10 \%$ of the households were selected randomly in each village.
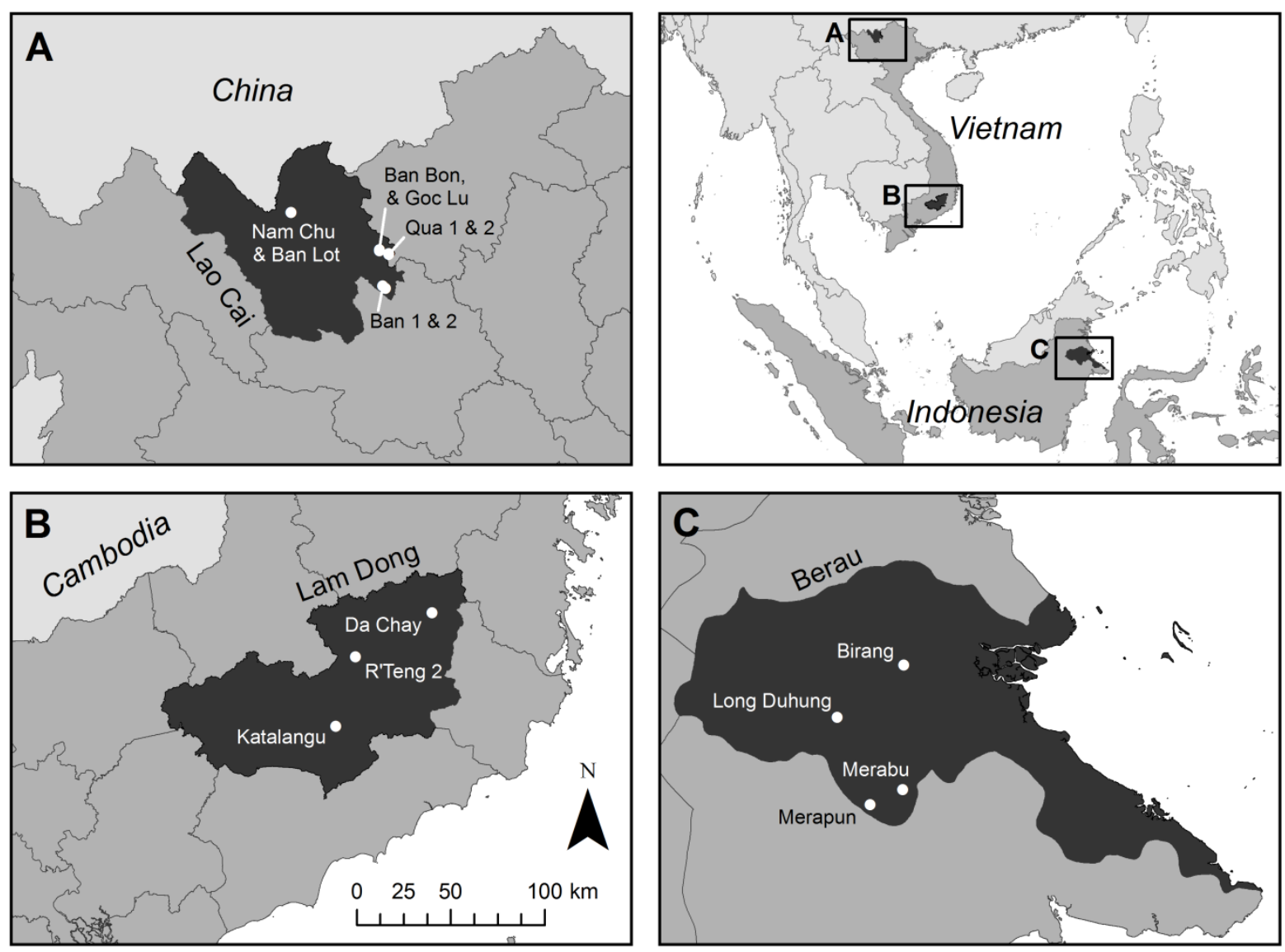

Figure 1 Maps showing locations of the study villages in A: Lao Cai Province, Vietnam; B: Lam Dong Province, Vietnam; and C: Berau Regency, Indonesia. Map source: The GADM database, downloaded from DIVA-GIS (http://www.diva-gis.org). 
Table 1 Number of households in study sites

\begin{tabular}{|c|c|c|c|c|}
\hline Province & District & Commune & Village & $\begin{array}{l}\text { Number of } \\
\text { households }\end{array}$ \\
\hline \multirow[t]{3}{*}{ Lam Dong, Vietnam } & Lam Ha & Phu Song & R'teng 2 & 101 \\
\hline & Di Linh & Bao Thuan & KaLaTanGu & 106 \\
\hline & Lac Duong & Da Nhim & DaChay & 8 \\
\hline \multirow[t]{3}{*}{ Lao Cai, Vietnam } & Bao Thang & Ban Cam & $\begin{array}{l}\text { Nam Chu and Ban } \\
\text { Lot (commune name } \\
\text { used) }\end{array}$ & 23 \\
\hline & \multirow[t]{2}{*}{ Bao Yen } & Xuan Hoa & $\begin{array}{l}\text { Ban Qua } 1 \text { and 2, Ban } \\
\text { Bon, Goc Lu } \\
\text { (commune name } \\
\text { used) }\end{array}$ & 60 \\
\hline & & Long Khanh & $\begin{array}{l}\text { Ban } 1 \text { and } 2 \\
\text { (commune name } \\
\text { used) }\end{array}$ & 55 \\
\hline \multirow{4}{*}{$\begin{array}{l}\text { Eastern Kalimantan, } \\
\text { Indonesia }\end{array}$} & \multirow[t]{3}{*}{ Berau } & \multirow[t]{3}{*}{ Kelay } & Merabu & 49 \\
\hline & & & Long Duhung & 24 \\
\hline & & & Merapun & 86 \\
\hline & Berau & Gunung Tabur & Birang & 41 \\
\hline Total & 7 & 8 & 15 & 553 \\
\hline
\end{tabular}

Source: Household survey, April 2016, August 2016 and April 2017

We evaluated the REDD+ activities at the national, provincial and commune levels and assessed the success of existing REDD+ activities based on the concretization of actions required to reach the objectives of the REDD+ readiness phase.

We adopted a two-stage approach. First, we explored how far Indonesia and Vietnam have progressed in terms of achieving core REDD+ design elements. The analysis was based on official documents published by the two governments and insights from discussions with key stakeholders. Our main analytical tool was to question stakeholders on the progress of the six core elements, and to consult central government or 
provincial documents to ascertain how far the countries had come in reaching operationalization based on pilot tests. Core REDD+ design elements lacking clear definition, which had not yet been tested, or for which government approval was still pending, were considered unsuccessful. In no document did we find a distinction between objectives in the readiness phase and implementation goals.

Second, we used a household survey (individual households) to evaluate local communities' knowledge and perceptions about REDD+. Here, we concentrated on three questions: how do you understand REDD+; is crop farming legal under the REDD+ regime; and do you fear that outsiders will receive the money in a future REDD+ benefit-sharing scheme? Finally, we examined changes in forest cover around the study villages, based on data from Global Forest Watch (Hansen et al. 2013).

\section{Results and discussion}

\subsection{National level}

The UN-REDD began operating in 2009 both in Indonesia and Vietnam (UN-REDD, 2010). In Indonesia, the government, through the national REDD+ agency, reported the establishment of a national emissions reference level, progress in the formulation of an MRV system, and the concretization of a national benefitsharing mechanism (World Bank, 2011; Republic of Indonesia, 2014). Today, the Directorate General of Climate Change under the Ministry of Environment and Forestry is in charge of REDD+ implementation and policies (P3SEKPI, 2017). The most notable policy intervention is the government's declaration of a moratorium on forest conversion in 2013, which is still in force. The government issued an MRV design document in 2015 and suggested that existing forest management units should oversee community involvement in REDD+ (Republic of Indonesia, 2015). However, a survey of 41 forest management units revealed that only $20 \%$ have completed any forest management plans (Bae et al., 2014). By contrast, Kim et al. (2016) found signs of improved forest governance, based on a case study. These authors suggest that to be fully operational, government policies should be more consistent and committed to strengthening the capacity of individual forest management units. No published document addresses the last requirement, i.e. government measures to promote a multi-stakeholder approach in forest policy formulation. Norway promised to transfer 1 billion \$ US if REDD+ initiatives were to pay off in terms of lower or falling deforestation rates, but in reality the Norwegian government hesitated to get involved in what they characterized as 'a bumpy journey' in Indonesia. To date, Norway has only disbursed approximately $8 \%$ of its pledged funds to Indonesia (Norwegian embassy, personal communication). 
In Vietnam, The Emission Reductions Program funded by the FCPF notes that the REDD+ program will be the first all-encompassing intervention in six provinces in Vietnam (Republic of Vietnam, 2016a). However, it is often overlooked that the first disbursement by the World Bank was in 2012. The year 2016 marked the Vietnamese government's official recognition that the REDD+ process has been far from smooth. The government failed to implement a national benefit-sharing mechanism, and with no monitoring system in place or a functional MRV, Vietnam completed an emission reductions report for the World Bank REDD+ system in 2016 (Republic of Vietnam, 2016a), requesting a financing package of \$50 million from the Carbon Fund (phase II). A technical assessment report raised several concerns that needed to be addressed before Vietnam could qualify for additional REDD+ funding. In particular, matching appropriate interventions to the drivers of deforestation remains unresolved, and the transformation of forest into plantation continues apace (FCPF, 2016). A single but significantly positive sign appears in the World Bank's technical assessment of the revised version, however. The World Bank revised assessment underlines technical improvements (consistency between the reference level and monitoring), better description of safeguards, and the expression of political will to lower the conversion of natural forests into plantations (FCPF, 2017). The Carbon Fund accepted the application from the Vietnamese government in 2018 (FCPF, 2018).

Table 2 summarizes progress in development of the core REDD+ elements during the readiness phase. An REL has been established in Vietnam based on the testing and development of maps, although FCPF inconsistencies with the MRV call for improvement and maybe a need to shift to another REL period (Republic of Vietnam, 2018; FCPF, 2018). By the same token, the FCPF found progress in the MRV system satisfactory. In both cases, REL and MRV, the Vietnamese government will have to endorse the technical framework. Likewise, although deforestation drivers were identified in all six provinces, no methodological section explains the ranking system used to identify the main drivers (Republic of Vietnam, 2018). In Indonesia, REL is in place, and MRV are being further developed in a number of projects with a view to improving the methodology. Progress is very slow in all other areas of core REDD+ elements (Republic of Indonesia, 2018). We interviewed several NGOs in the two countries, and they were neither involved nor consulted in the RELMRV processes, nor in identifying the deforestation drivers.

The REDD+ process has been in the making for 7-8 years, and both countries have made little progress, with Indonesia falling behind even compared to Vietnam. The less technical pillars, social safeguards and multiactor negotiations, are apparently the most difficult issues for the two governments to address. 
Table 2: Summary of progress in the core REDD+ elements, Indonesia and Vietnam, 2018 (national level)

\begin{tabular}{|c|c|c|c|c|}
\hline $\begin{array}{ll}\text { Core } & \text { REDD+ } \\
\text { elements } & \end{array}$ & Indonesia & Vietnam & $\begin{array}{l}\text { Comment, } \\
\text { Indonesia }\end{array}$ & $\begin{array}{l}\text { Comment, } \\
\text { Vietnam }\end{array}$ \\
\hline $\begin{array}{l}\text { Identification of } \\
\text { deforestation } \\
\text { drivers }\end{array}$ & $\begin{array}{l}\text { No reference to } \\
\text { deforestation } \\
\text { drivers }\end{array}$ & $\begin{array}{l}\text { Main } \\
\text { deforestation } \\
\text { drivers identified }\end{array}$ & & $\begin{array}{l}\text { Official } \\
\text { acknowledgement } \\
\text { of deforestation } \\
\text { being an issue. Link } \\
\text { to REDD+ policies } \\
\text { is not clear. }\end{array}$ \\
\hline $\begin{array}{l}\text { REL (Reference } \\
\text { Emission Level) }\end{array}$ & Finalized in 2017 & $\begin{array}{l}\text { REL to be approved } \\
\text { by government }\end{array}$ & $\begin{array}{l}\text { Link to MRV not } \\
\text { yet established }\end{array}$ & $\begin{array}{l}\text { No time window } \\
\text { for government } \\
\text { endorsement }\end{array}$ \\
\hline MRV & $\begin{array}{l}\text { Principles } \\
\text { developed in } 2016 . \\
\text { Training of staff is } \\
\text { ongoing }\end{array}$ & $\begin{array}{l}\text { Principles } \\
\text { developed over } \\
\text { the years. } \\
\text { Requires } \\
\text { government } \\
\text { approval } \\
\end{array}$ & $\begin{array}{l}\text { Not implemented } \\
\text { anywhere in } \\
\text { Indonesia }\end{array}$ & $\begin{array}{l}\text { No time window } \\
\text { for government } \\
\text { endorsement }\end{array}$ \\
\hline $\begin{array}{l}\text { Multi-actor } \\
\text { negotiations }\end{array}$ & $\begin{array}{l}\text { Public } \\
\text { consultations only }\end{array}$ & $\begin{array}{l}\text { Stakeholders at } \\
\text { the household } \\
\text { level involved in } \\
\text { consultation. }\end{array}$ & $\begin{array}{l}\text { Less attention to } \\
\text { this issue than in } \\
\text { Vietnam }\end{array}$ & $\begin{array}{l}\text { Not clear how } \\
\text { households and } \\
\text { communities will } \\
\text { get involved in } \\
\text { forest } \\
\text { management } \\
\text { planning (FMP) }\end{array}$ \\
\hline $\begin{array}{l}\text { Benefit-sharing } \\
\text { mechanisms }\end{array}$ & No trial anywhere & No trial anywhere & & \\
\hline Social safeguards & Not yet addressed & $\begin{array}{l}\text { Issue addressed, } \\
\text { including } \\
\text { customary rights. }\end{array}$ & & $\begin{array}{lr}\text { Not clear } & \text { how } \\
\text { safeguards } & \text { will } \\
\text { affect FMP } & \\
\end{array}$ \\
\hline
\end{tabular}

Source:

Republic of Indonesia. (2018). Emission Reductions Program Document (ER-PD). Jakarta, Indonesia.

Republic of Vietnam, Ministry of Agriculture and Rural Development (2018). Emission Reductions Program Document (ER-PD) 


\subsection{Provincial level}

Experiences in REDD+ projects on the ground in Indonesia vary more than in Vietnam. The Indonesian government allowed many actors to design their own implementation models, and we would therefore expect that a wider range of ideas would have been tested. Based on information from other analyses of REDD+ projects and our own investigation in four villages, the end result is surprisingly similar, however. Often, if not always, REDD+ projects had shifted from their core objective to reduce emissions in the future, to a focus on multi-stakeholder interaction that emphasizes reconciling opposing user preferences when it comes to the exploitation of forest resources. In socioeconomic settings where conflicts had been simmering for a long time, the arrival of the REDD+ projects had little to offer. In one NGO-managed project in central Kalimantan (Hawson and Kindon, 2015) and another in eastern Kalimantan (our field area), local villagers were unable to influence the provincial administration in what they saw as dubious deals with developers. Villagers joined the REDD+ project either because it gave them access to financial capital (central Kalimantan), or because they succeeded in persuading the NGO in question to act as a mediator in forest rights conflicts (eastern Kalimantan). In other projects, REDD+ readiness activities came to a halt due to local resistance, because villagers feared they could lose their land as a result of a survey of existing boundaries. Examples were an Australian-funded project in Central Kalimantan (Agung et al., 2014 and Howell, 2015), and a review of a UN-REDD project in Central Sulawesi (Howell, 2015). Today, REDD+ projects are practically all concentrated on Kalimantan and are funded by the FCPF or the German government (FORCLIME, 2013). Problems with forest management in eastern Kalimantan centre on conflicts over access to land. REDD+ programs will have to broaden the inclusion of stakeholders, and include foreign mining or logging firms, in order to solve these conflicts. In general, in REDD+ programs relationships are currently only designed to articulate between the global level (donors), the government and the local people (FCPF, 2008 and 2017). We are not familiar with any REDD+ program that allows the voice of large corporations to modify the general picture of a REDD+ program (interviews with German and Japanese project leaders)

The overall objectives in the planning process are defined at the provincial level, with little power left to the district level. A pervasive problem is a provincial-level policy of granting concessions to economic activities, whether related to mining, logging or palm oil plantations. Sunderlin et al. (2014) identified various factors favoring or undermining REDD+ projects at the local level, one of which is that the national and local levels often issue overlapping forest licenses. If a new provincial policy aims to curb emissions and conserve the forest, companies often request compensation. A review article on the REDD+ debate characterized the benefit-sharing theme as crucial and compared it with the opportunity costs of land (Mbatu, 2016). The value of alternative uses of land (foregone benefits) compared to actual carbon prices on world markets is often 
used as a proxy for conservation costs in Indonesia (for example Terauchi, 2014 and Resosudarmo et al., 2014). However, these authors underestimate the real opportunity or conservation costs that would be incurred if the potential compensation were paid to foreign exploitation firms instead of to local farmers. Land allocation is firmly underway in Indonesia, although there are challenges in the form of disputes over land tenure between local people, the state and enterprises. As a result of the continuous struggle for land and land disputes, overlapping maps probably exist in most of rural Indonesia (Kunz et al., 2017). The former REDD+ Agency suggested introducing a One Map Policy to make up for the absence of a single reference system that could be used by all ministries (Wilbowo and Giessen, 2015). The One Map Policy is technically feasible but any application is likely to face political obstacles due to different interests among the ministries, as noted by the authors. In 2018, the government finalized the mapping of the last three islands (The Jakarta Post, 2018).

Vietnam presents a different case, as the state controls or seeks to control all forestry activities in the country. The UN-REDD has suggested initiating and monitoring forest activities in six provinces, and the World Bank concentrates its activities in another five provinces (UN-REDD, 2013; FCPF, 2017). In Vietnam, the Department of Agriculture and Rural Development issued a provincial REDD+ report (for Lam Dong province) in 2014 (PRAP), containing an analysis of carbon emissions drivers and scenarios regarding the possible effects of government interventions in the forestry sector (DARD, 2014). However, the report omitted any discussion of the lack of concrete local activities in the province, and engaged in a lengthy presentation of various benefit-sharing schemes, steering clear of any reference to the de facto situation in Lam Dong. Later, data collection and preliminary analyses of forest drivers in five other provinces fed into the Vietnamese government's ER-PD (Emission Reduction Program Document) to support a request for further funding from the World Bank (Republic of Vietnam, 2016a). Here, it appeared that the provinces acted more as service providers than active stakeholders in policy framing in Vietnam. The offices we visited in Lam Dong and Lao Cai had not organized any formal meetings with the villagers. Brockhaus et al. (2014) describe approaches like those applied in the Lam Dong provincial REDD+ report as 'the business-as-usual approach (BAU)', characterized by not directly defending policies leading to deforestation, but ignoring domestic factors and focusing exclusively on securing external funding.

The UN-REDD office in Lam Dong (Vietnam) is the only province to have issued a regional document (DARD, 2014). The provincial action plan estimates carbon emissions and outlines a number of scenarios based on more or less reduction in forest conversion. Ideas to develop MRV principles and adopt them in the province are presented in the report. Several NGOs in Vietnam mentioned provinces' complaints that few funds 
filtered down to the provincial level, and in the provincial meetings staff observed that they did not receive any additional payments for services provided within the REDD+ framework.

\subsection{Commune level}

We examined REDD+ local activities in the two countries and posed villagers similar questions about basic economic characteristics and their attitudes towards REDD+. Initially, we sought to compare people's strategies before and after donors or local authorities had experimented with REDD+ benefit-sharing schemes or had explained to locals about their forest rights under REDD+. However, in none of the sites we visited had REDD+ activities taken off yet. The UN-REDD office in Hanoi claimed that the agency was taking steps to implement local activities in Lam Dong from 2016. Most activities included support for local people, consisting of clothes and fertilizer. While beneficial to the locals any link to REDD+ objectives was absent, such as benefit sharing, involvement of stakeholders, or the ultimate goal to slow down deforestation rates. Pilot REDD+ forests in Lam Dong province (Vietnam) are marginal in size (100-300 hectares) and build on existing and relatively well-functioning forest protection schemes. Apart from the identification of target forest areas in the two countries, we found no monitoring of forest cover over time or assessment of household compliance with rules (rules are often only explained verbally).

In the household survey, we first asked villagers how they understood REDD+ regulations. Most villagers in the two provinces in Vietnam were familiar with the forest protection provision in REDD+, but correct response rates were significantly lower in Indonesia (Table 3). Regarding the question of whether farming inside forests was permitted under REDD+ regulations, there were substantial differences in responses. In only two out of a total of 9 villages (R'teng 2 in Vietnam and Merabu in Indonesia) did a majority of the population recognize correctly that crop farming is not allowed inside REDD+ assigned forests (Table 4) Forest protection in these two villages existed well before any discussion about REDD+ was put on the agenda.

In a future scenario with payments for carbon rights or forest protection, villagers were requested to answer whether they thought outsiders would receive the money. Villagers in Vietnam were clearly more concerned about outside seizure of their rights to compensation (Table 5).

Few villagers, regardless of province and country, can claim legal tenure on forest areas. Almost none of the $500+$ households we interviewed could demonstrate ownership of forest plots in the form of a deed or red book certificate (Vietnam). In both countries, forest areas belong to the state, and forest land allocation is characterized by the prevalence of concessions to the state or private companies. Local REDD+ activities in 
the villages have virtually no bearing on the impact of REDD+ policies as long as de facto national forest issues are negotiated between governments and state/private companies. While the tenure situation regarding land other than dwellings is uncertain in both countries, we know from interviews that conflicts exist in both countries between households and the state or private companies. We did not embark on a specific analysis of deforestation drivers, but the fact that we noticed conflicts between locals and companies (state and private) in all sites suggests who/what could be the main deforestation drivers.

Benefit-sharing schemes and social safeguards require local experience and involvement, but neither of the two main international organisations, the UN-REDD or the FCPF, arranged meetings or discussed these issues with locals in either of the two countries. Only JICA (Japanese International Cooperation Agency) piloted benefit distribution schemes in the northern province of Dien Bien during the project period (JICA, 2015).

Table 3 How do you understand REDD+? Household data from Vietnam and Indonesia

\begin{tabular}{|c|c|c|c|c|c|c|c|c|c|c|c|}
\hline \multirow[b]{2}{*}{$\begin{array}{l}\text { How do you understand } \\
\text { REDD? }\end{array}$} & \multicolumn{3}{|c|}{ Lam Dong, Vietnam } & \multicolumn{3}{|c|}{ Lao Cai, Vietnam } & \multicolumn{4}{|c|}{ Kalimantan, Indonesia } & \multirow[b]{2}{*}{ Total } \\
\hline & DaChay & KaLaTanGu & $\begin{array}{l}R^{\prime} \text { teng } \\
2\end{array}$ & $\begin{array}{l}\text { Ban } \\
\text { Cam }\end{array}$ & $\begin{array}{l}\text { Long } \\
\text { Khanh }\end{array}$ & $\begin{array}{l}\text { Xuan } \\
\text { Hoa }\end{array}$ & Merabu & $\begin{array}{l}\text { Long } \\
\text { Duhung }\end{array}$ & Merapun & Birang & \\
\hline Control of forest & $\begin{array}{l}0 \\
0.00\end{array}$ & $\begin{array}{l}1 \\
1.0\end{array}$ & $\begin{array}{l}1 \\
1.0\end{array}$ & & & & $\begin{array}{l}0 \\
0.00\end{array}$ & $\begin{array}{l}2 \\
8.3\end{array}$ & 8 & $\begin{array}{l}0 \\
0.00\end{array}$ & 12 \\
\hline Don't know & $\begin{array}{l}7 \\
87.5\end{array}$ & $\begin{array}{l}25 \\
23.8\end{array}$ & $\begin{array}{l}35 \\
34.7\end{array}$ & $\begin{array}{l}10 \\
43.5\end{array}$ & $\begin{array}{l}12 \\
21.8\end{array}$ & $\begin{array}{l}31 \\
52.5\end{array}$ & $\begin{array}{l}26 \\
53.1\end{array}$ & $\begin{array}{l}13 \\
54.2\end{array}$ & $\begin{array}{l}36 \\
41.9\end{array}$ & $\begin{array}{l}30 \\
73.2\end{array}$ & 225 \\
\hline Forest protection & $\begin{array}{l}1 \\
12.5\end{array}$ & $\begin{array}{l}78 \\
74.3\end{array}$ & $\begin{array}{l}59 \\
58.4\end{array}$ & $\begin{array}{l}11 \\
47.8\end{array}$ & $\begin{array}{l}38 \\
69.1\end{array}$ & $\begin{array}{l}26 \\
44.1\end{array}$ & $\begin{array}{l}19 \\
38.8\end{array}$ & $\begin{array}{l}9 \\
37.5\end{array}$ & $\begin{array}{l}39 \\
45.4\end{array}$ & $\begin{array}{l}8 \\
19.5\end{array}$ & 288 \\
\hline $\begin{array}{l}\text { Compensation for forest } \\
\text { protection }\end{array}$ & $\begin{array}{l}0 \\
0\end{array}$ & $\begin{array}{l}1 \\
1.0\end{array}$ & $\begin{array}{l}6 \\
5.9\end{array}$ & $\begin{array}{l}2 \\
8.7\end{array}$ & 5 & $\begin{array}{l}2 \\
3.4\end{array}$ & $\begin{array}{l}3 \\
6.1\end{array}$ & $\begin{array}{l}0 \\
0\end{array}$ & $\begin{array}{l}1 \\
1.2\end{array}$ & $\begin{array}{l}1 \\
2.4\end{array}$ & 21 \\
\hline Total & 8 & 105 & 101 & 23 & 55 & 59 & 48 & 24 & 84 & 39 & 546 \\
\hline
\end{tabular}

Source: Household survey, April 2016, August 2016 and April 2017 (figures in brackets indicate percentage of total) 
Table 4 Is crop farming legal or not under REDD+? Household data from Vietnam and Indonesia

\begin{tabular}{|c|c|c|c|c|c|c|c|c|c|c|c|}
\hline \multirow[b]{2}{*}{$\begin{array}{l}\text { Is crop farming legal or not } \\
\text { under REDD+? }\end{array}$} & \multicolumn{3}{|c|}{ Lam Dong, Vietnam } & \multicolumn{3}{|c|}{ Lao Cai, Vietnam } & \multicolumn{4}{|c|}{ Kalimantan, Indonesia } & \multirow[b]{2}{*}{ Total } \\
\hline & DaChay & KaLaTanGu & $\begin{array}{l}R^{\prime} \text { teng } \\
2\end{array}$ & $\begin{array}{l}\text { Ban } \\
\text { Cam }\end{array}$ & $\begin{array}{l}\text { Long } \\
\text { Khanh }\end{array}$ & $\begin{array}{l}\text { Xuan } \\
\text { Hoa }\end{array}$ & Merabu & $\begin{array}{l}\text { Long } \\
\text { Duhung }\end{array}$ & Merapun & Birang & \\
\hline Not allowed & 1 & $\begin{array}{l}57 \\
57.6\end{array}$ & $\begin{array}{l}72 \\
90.0\end{array}$ & $\begin{array}{l}8 \\
34.8\end{array}$ & $\begin{array}{l}18 \\
32.7\end{array}$ & $\begin{array}{l}18 \\
30.0\end{array}$ & $\begin{array}{l}15 \\
53.6\end{array}$ & $\begin{array}{l}1 \\
12.5\end{array}$ & $\begin{array}{l}20 \\
24.1\end{array}$ & $\begin{array}{l}7 \\
22.6\end{array}$ & 217 \\
\hline Allowed partly & 0 & $\begin{array}{l}4 \\
4.0\end{array}$ & $\begin{array}{l}2 \\
2.5\end{array}$ & $\begin{array}{l}2 \\
8.70\end{array}$ & $\mid \begin{array}{l}7 \\
12.7\end{array}$ & $\begin{array}{l}10 \\
16.7\end{array}$ & $\begin{array}{l}2 \\
7.1\end{array}$ & $\begin{array}{l}1 \\
12.5\end{array}$ & $\begin{array}{l}1 \\
1.2\end{array}$ & $\begin{array}{l}3 \\
10.0\end{array}$ & 32 \\
\hline Allowed freely & $\begin{array}{l}4 \\
50.0\end{array}$ & $\begin{array}{l}1 \\
1.0\end{array}$ & 0 & $\begin{array}{l}8 \\
34.78\end{array}$ & $\begin{array}{l}21 \\
38.2\end{array}$ & $\begin{array}{l}16 \\
26.7\end{array}$ & & & & & 46 \\
\hline Don't know & 1 & $\begin{array}{l}37 \\
37.4\end{array}$ & $\begin{array}{l}6 \\
7.5\end{array}$ & $\begin{array}{l}5 \\
21.74\end{array}$ & $\mid \begin{array}{l}9 \\
16.4\end{array}$ & $\begin{array}{l}16 \\
26.67\end{array}$ & $\begin{array}{l}6 \\
21.4\end{array}$ & 5 & $\begin{array}{l}38 \\
45.8\end{array}$ & $\begin{array}{l}10 \\
32.3\end{array}$ & 132 \\
\hline Don't understand & $\begin{array}{l}2 \\
25.0\end{array}$ & & & & & & $\begin{array}{l}5 \\
17.9\end{array}$ & $\begin{array}{l}1 \\
12.50\end{array}$ & $\begin{array}{l}24 \\
28.9\end{array}$ & $\begin{array}{l}11 \\
35.45\end{array}$ & 41 \\
\hline Total & 8 & 99 & 80 & 23 & 55 & 60 & 28 & 8 & 83 & 31 & 475 \\
\hline
\end{tabular}

Source: Household survey, April 2016, August 2016 and April 2017 (figures in brackets indicate percentage of total)

Table 5 Are you afraid that outsiders will receive the money and not you? Household data from Vietnam and Indonesia

\begin{tabular}{|c|c|c|c|c|c|c|c|c|c|c|c|}
\hline \multirow[b]{2}{*}{$\begin{array}{l}\text { Are you afraid that outsiders } \\
\text { will receive the money and not } \\
\text { you? }\end{array}$} & \multicolumn{3}{|c|}{ Lam Dong, Vietnam } & \multicolumn{3}{|c|}{ Lao Cai, Vietnam } & \multicolumn{4}{|c|}{ Kalimantan, Indonesia } & \\
\hline & DaChay & KaLaTanGu & $\begin{array}{l}R^{\prime} \text { teng } \\
2\end{array}$ & $\begin{array}{l}\text { Ban } \\
\text { Cam }\end{array}$ & $\begin{array}{l}\text { Long } \\
\text { Khanh }\end{array}$ & $\begin{array}{l}\text { Xuan } \\
\text { Hoa }\end{array}$ & Merabu & $\begin{array}{l}\text { Long } \\
\text { Duhung }\end{array}$ & Merapun & Birang & Total \\
\hline No & $\begin{array}{l}4 \\
50.0\end{array}$ & $\begin{array}{l}66 \\
62.3\end{array}$ & $\begin{array}{l}65 \\
64.34\end{array}$ & $\begin{array}{l}12 \\
52.2\end{array}$ & $\begin{array}{l}36 \\
65.5\end{array}$ & $\begin{array}{l}35 \\
58.3\end{array}$ & $\begin{array}{l}40 \\
81.6\end{array}$ & $\begin{array}{l}21 \\
87.5\end{array}$ & $\begin{array}{l}85 \\
98.8\end{array}$ & $\begin{array}{l}29 \\
70.7\end{array}$ & 389 \\
\hline Yes & 0 & $\begin{array}{l}16 \\
15.1\end{array}$ & $\begin{array}{l}13 \\
12.9\end{array}$ & $\begin{array}{l}5 \\
21.7\end{array}$ & $\begin{array}{l}10 \\
18.2\end{array}$ & $\begin{array}{l}10 \\
16.7\end{array}$ & $\begin{array}{l}4 \\
8.2\end{array}$ & $\begin{array}{l}0 \\
0\end{array}$ & $\begin{array}{l}1 \\
1.2\end{array}$ & $\begin{array}{l}8 \\
19.5\end{array}$ & 67 \\
\hline Don't know & $\begin{array}{l}4 \\
50.0\end{array}$ & $\begin{array}{l}24 \\
22.6\end{array}$ & $\begin{array}{l}23 \\
22.8\end{array}$ & $\begin{array}{l}6 \\
26.1\end{array}$ & $\begin{array}{l}9 \\
16.4\end{array}$ & $\begin{array}{l}15 \\
25 .\end{array}$ & $\begin{array}{l}5 \\
10.2\end{array}$ & $\begin{array}{l}3 \\
12.5\end{array}$ & $\begin{array}{l}0 \\
0\end{array}$ & $\begin{array}{l}4 \\
9.8\end{array}$ & 89 \\
\hline Total & 8 & 106 & 101 & 23 & 55 & 60 & 49 & 24 & 86 & 41 & 553 \\
\hline
\end{tabular}

Source: Household survey, April 2016, August 2016 and April 2017 (figures in brackets indicate percentage of total) 


\subsection{Tree cover changes at sites}

Tree cover in $\mathbf{2 0 0 0}$ was much higher in the Indonesian sites (e.g. lowest at $84 \%$ in Birang and approximately 97\% in Merabu, Merapun and Long Duhung at 50\% tree canopy density; Fig. 2 than in the Vietnamese sites (although it was 80\% in Da Chay and 66-71\% in Ban 1 and 2, Long Khan commune). In all locations apart from Kalatangu, tree cover was higher in 2000 than in 2010, irrespective of the applied tree canopy density threshold. Comparing the period 2001-2013 to the period 2013-2016 - roughly equivalent to before and after implementation of REDD+ pilot projects in the two countries - the loss of tree-covered area per year increased slightly in Merabu but declined in Birang, Indonesia $(0.34 \rightarrow 1.38$ and $3.4 \rightarrow 2.09 \%$ at $50 \%$ tree canopy density (see Fig. 3). In the later period, the loss per year of areas with more than $50 \%$ tree canopy density remained low in $\mathrm{R}^{\prime}$ Teng 2 and Kalatangu (0.32 and 0.05\%), declined in Qua 1 and $2(0.16 \rightarrow 0.06 \%)$ but increased in Ban 1 and 2 , Vietnam $(0.16 \rightarrow 0.70$ and $0.16 \rightarrow 0.66 \%)$. Applying a definition of $75 \%$ canopy density reduces the tree cover change (2000-2010) by 7-10\% points in the middle range sites (Xuan Hoa and Nam Chu in Vietnam) and increases the change in areas experiencing high deforestation rates (Merabu in Indonesia and Da Chay in Vietnam). In most other sites, using another tree canopy cover definition does not change the picture very much.

Figures 2 and 3 also enable comparison of changes in tree cover in the applied $5 \mathrm{~km}$ radius around villages, with change in a $10 \mathrm{~km}$ radius (filled and open circles on the bars). In most cases, Figure 1 reveals higher forest cover beyond the $5 \mathrm{~km}$ radius in both 2000 and 2010, and a lower percent of annual loss both in 20012013 and 2014-2016, suggesting that the $5 \mathrm{~km}$ radius quite accurately reflects villages' sphere of influence, although potential overlaps with areas around neighbouring villages are not considered. The few exceptions include Ban 1 and 2 in Vietnam, with lower average tree cover in the $10 \mathrm{~km}$ radius than the $5 \mathrm{~km}$ radius in both 2000 and 2010, and higher percent annual loss in 2014-2016. In Indonesia, tree cover was slightly lower in the $10 \mathrm{~km}$ radius which, for 2010, may be explained by a plantation spreading fom the west starting in 2008-9 (Google Earth historical maps). This may also explain the higher percentage of annual loss in Merabu in the period 2001-2013, while for Birang the continued expansion since the 1990s of mining and logging concessions may explain the higher percentage annual loss in the $10 \mathrm{~km}$ radius.

Because the UN and the World Bank never initiated real local REDD+ activities and, if anything, only partially focused on forest monitoring, and because most of the forest was outside the reach of REDD+ policy interventions anyway, the continuing loss of forest in these sites cannot be ascribed to policy failures within 
a REDD+ framework. However, the data show that two sites in Indonesia (Merabu and Long Duhun) fared quite well in forest protection. In both villages, forest protection preceded the idea of REDD+. Conflicts are more open in Long Duhun, and the NGO 'The Nature Conservancy' seeks to mediate between the villagers and the local mining and logging firms. In Long Duhung, households were very reliant on access to forest products. A threat from a neighboring palm oil plantation could change the relative calm in Merabu in the future. Another issue is that forest quality in terms of forest coverage is higher or much higher in Indonesia compared to Vietnam (Figure 2).

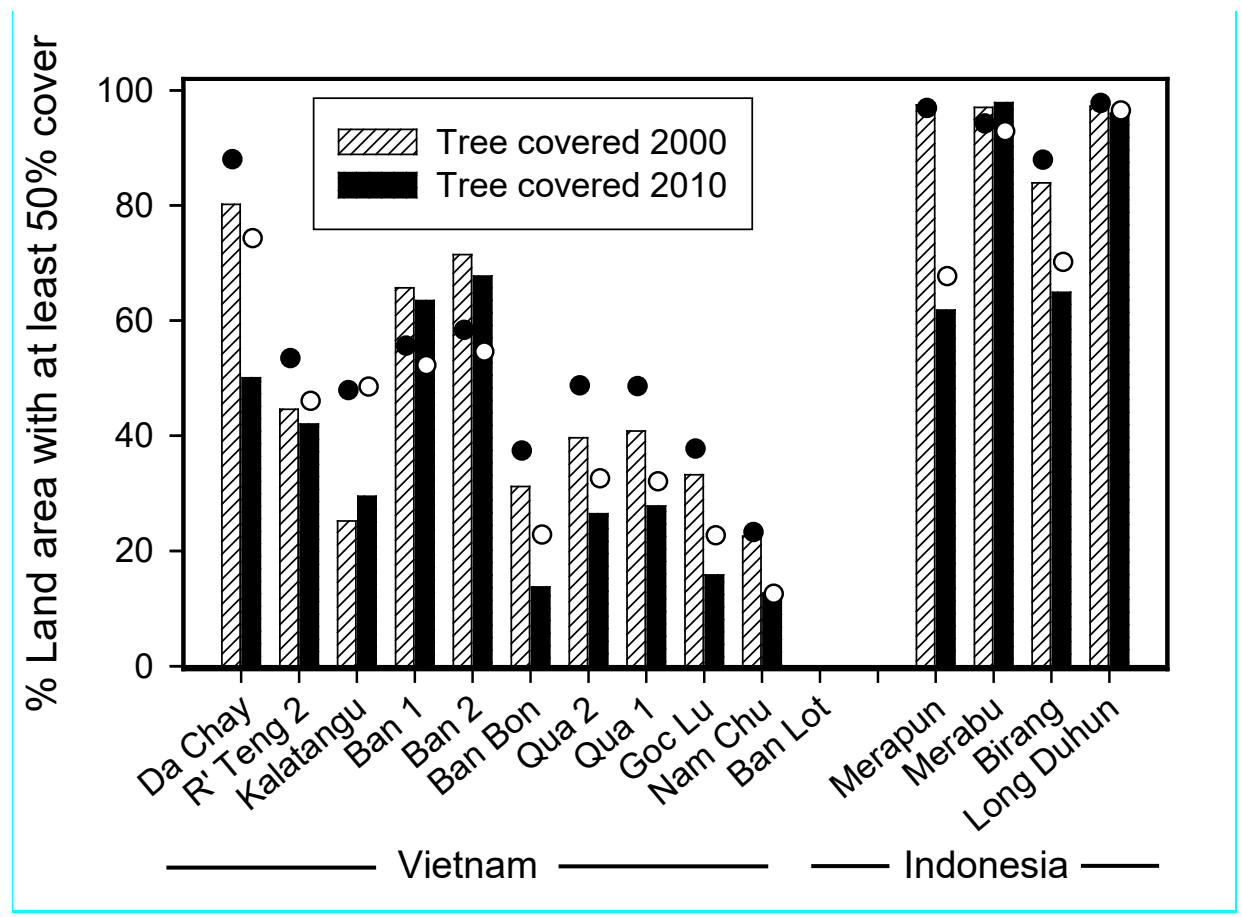

Figure 2 Per cent forest in 2000 and 2010, expressed as land with at least 50\% tree cover within 5 km radius (vertical bars) and $10 \mathrm{~km}$ (circles) around each village. Source: Global Forest Watch (https://www.globalforestwatch.org). 


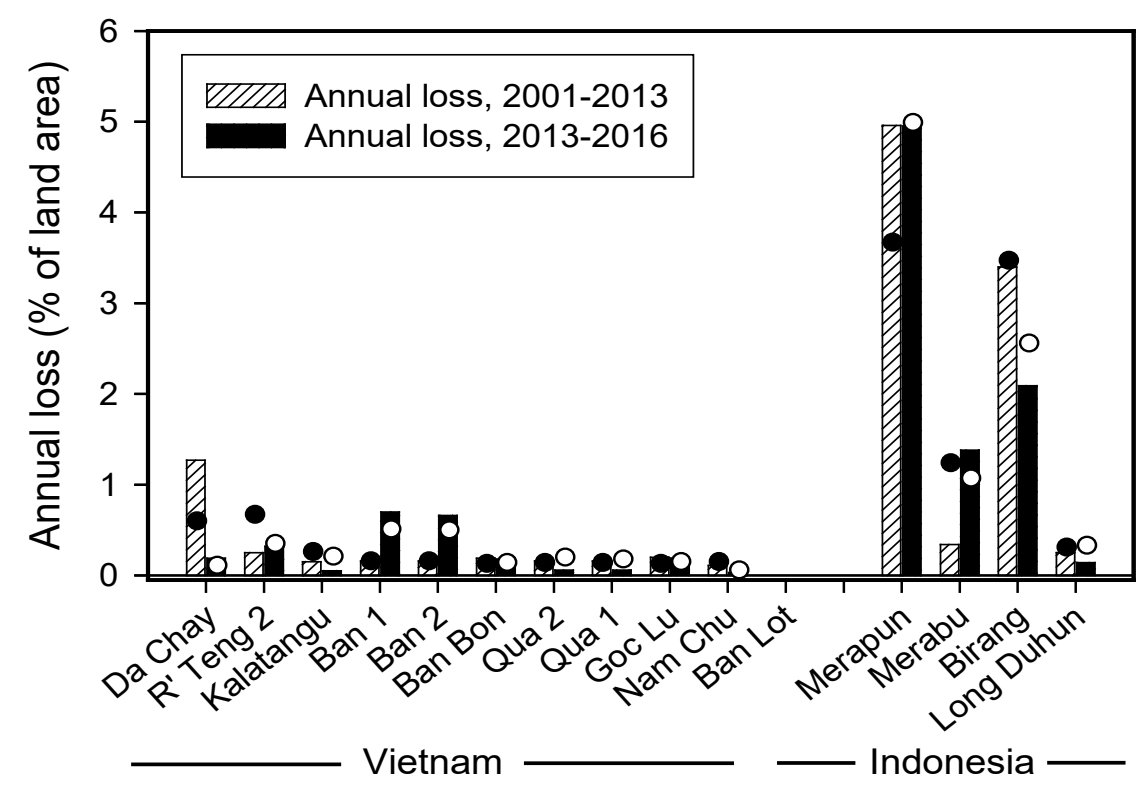

Figure 3 Annual loss of forest (land with at least 50\% tree cover) within a $5 \mathrm{~km}$ radius (vertical bars) and 10 km (circles) around each village, calculated for 2001-2013 and 2013-2016 and expressed as per cent of land area. Source: Global Forest Watch (https://www.globalforestwatch.org).

\section{Conclusions}

Our analysis reveals two possible explanations for the failure in the REDD+ readiness phase in Indonesia and Vietnam. For a long time - six to seven years in fact - international objectives for capacity building have placed a strong emphasis on procedural policy tools, such as the development of steering committees, training and outreach, which were often treated as end goals in themselves. Of the six core REDD+ elements, Indonesia has defined an REL and is in the process of defining an MRV. Vietnam has both an REL and an MRV ready for final government approval, although it has not provided any time window for endorsement. The main deforestation drivers have been identified in Vietnam, however the government has yet to supply information about the ranking system (methodology). The three remaining core REDD+ elements: multi-actor negotiations, benefit-sharing mechanisms, and social safeguards are hardly discussed or if a document does raise the issue (social safeguards in Vietnam) the connection to other core elements lacks clarification. Qualitative information, mainly from interviews with NGOs, confirms this impression.

The primary goals of stopping deforestation and promoting transparent governance appear to have been overlooked in the frantic race to reach the implementation phase. External and independent monitoring might have addressed the main issues, but the question is whether the REDD+ track record is so poor already 
that no optimism can be mustered to save the model. Donors and multilateral organizations were eager to get the readiness process launched in 2010/2011 shortly after the COP meeting in 2009, where REDD+ made it to the final document (UNFCC, 2010). The objectives of the readiness phase were never clearly specified or linked to the final objectives of REDD+ during the implementation phase, namely curbing carbon emissions by lowering the deforestation and degradation process.

Seen from a global perspective, there is a tendency towards more critical assessments of the feasibility of REDD+. That said, analyses often differ in terms of scale and definition of the type of challenges involved. To some observers, the challenges are of a technical nature. International organizations should resolve technical obstacles, such as the representativeness of projects, in order to enable upscaling to the national level, and should also address leakage issues and how to reach climate efficiency (Fischer et al., 2016).

Another school of observers looks beyond issues of measurement and addresses forest definitions, classifying forest in remote areas as 'degraded' or low productivity forest. This, in turn, justifies the wholesale clearing of secondary and even primary forest and conversion for plantation purposes (Barr and Sayer, 2012). Both in Indonesia and Vietnam, forest officials used the term 'low productivity' forest. Others have spoken of 'conservation fads' and referred to REDD+ as a discursive commodity at 'a moment in time when we cannot afford to waste financial resources on hot air' (Lund et al., 2016: 134).

We argue, conversely, that the main problem is not technical issues or conservation fads, but the contrast between the global governance model and the national political reality. Political will to address deforestation drivers is crucial if REDD+ national policies are to stand a chance of succeeding. In Vietnam, political preoccupation with gaining international approval and faith in the government's sincerity have increased during the REDD+ readiness phase, whereas Indonesia shows little sign of modifying its initial business-asusual approach. Vietnam attained endorsement from the World Bank to benefit from the Carbon Fund's financial resources. Provinces are supposed to deliver studies to the central government on deforestation drivers and forest types in order to calibrate potential carbon sequestration (Republic of Vietnam, 2017). However, the provinces acted more as service providers than key agents in shaping the readiness phase. In Indonesia, REDD+ activities are all concentrated on one island (Kalimantan), and coordination between the central and regional levels is no longer essential. An obvious reason for this concentration could be past decentralization and coordination issues, as we discussed above. The FCPF is the only major REDD+ international institution, and monitoring has become easier due to this move to regional and donor concentration. However, nobody in Indonesia seems concerned about scaling up aspects of the Kalimantan experience, if the case study should one day prove successful. Local REDD+ activities are almost absent in both countries. 
Findings regarding local perceptions of REDD+ activities were discussed with the UN-REDD in Hanoi, and representatives here acknowledged shortcomings but claimed that enhanced future efforts by the UN would rectify the situation. When the authorities in both countries, at the central or provincial level, did recognize challenges with REDD+ and conceded or accepted criticism of slow progress in reaching the implementation phase, they insisted that it had to do with complex UN-REDD budgetary procedures and overly restrictive conditions for disbursements.

If REDD+ ever reaches the implementation stage, donors will have to address the issue of mistrust in Vietnam. In both countries, approximately $70 \%$ of villagers prefer to own their forest lot, and in many cases, villagers see this as an opportunity to increase their area of agricultural land. In general, local villagers in both countries were totally unacquainted with the implications of the REDD+ program. They did not entirely oppose the idea of forest protection, e.g. in Indonesia $44 \%$ of the villagers were in favor of protection. However, in general respondents expressed uneasiness with the official system (both countries) and the risk of outsiders grabbing their land (Vietnam). If the pilot programs are representative of the UN-REDD campaign capacity, the result does not allow for much optimism. Only in R'teng 2 in Lam Dong province in Vietnam did the majority of the local population know about forest protection and the ban on agriculture in the protected forests, and felt reasonably confident that their forest would not end up in the hands of outsiders.

A focus on poor forest dwellers (FCPF, 2008 and 2017) in the design of REDD+ rules out all the major stakeholders, i.e. state/private logging firms and mining companies, from declaring emissions targets in national carbon reduction action plans. National emission reductions programs risk falling short of the Paris agreement targets (intended nationally determined contributions, INDC) if the actual deforestation drivers (state and private companies) are not addressed and the currently high deforestation rates continue. According to the Indonesian government, $63 \%$ of the country's emissions stem from land use changes, and the government has pledged to reduce emissions by $26 \%$ against a business-as-usual scenario by 2020 (Republic of Indonesia, 2016). In the case of Vietnam, the government has presented two strategies - for a decrease in emission intensity (energy consumption per GDP unit) and an increase in forest cover - resulting in a reduction of $8 \%$ against a business-as-usual scenario in 2030 (Republic of Vietnam, 2016b). In both countries, the REDD+ governance design is ill-suited to curbing carbon emissions that occur outside the control of small forest dwellers.

In both Indonesia and Vietnam, the readiness phase emphasized policy framing with few concrete and painstaking measures identified to meet the INDC that the two countries reported at the Paris COP meeting. None of the main REDD+ pillars - drivers of deforestation, REL, MRV, multi-actor negotiation, benefit-sharing schemes, social safeguards or on the ground experiences with REDD+ at the local level - have yet been fully 
addressed and operationalized. Of the two countries, Indonesia seems the least likely to muster the political will to change the business-as-usual approach enshrined in the national strategy, which puts economic and social development first and climate change second. Only the coming years will demonstrate whether the Vietnamese government's seeming new commitment is backed up by action or whether what we are witnessing is mere lip service rather than concrete climate-friendly action. Many of the required actions from the Vietnamese government fall naturally within a readiness phase framework. However, the World Bank has allowed the preparatory work (readiness phase related activities) to continue into the implementation phase. 
Ref:

Agung, P., Galudra, G., van Noordwijk, M., \& Maryani, R. (2014). Reform or reversal: the impact of REDD+ readiness on forest governance in Indonesia. Climate Policy, 14, 748-768.

Bae, J.S., Kim, Y.S., Fisher, L.A., Moelione, M., \& DeShazo, J. (2014). Promises and perils of decentralized forest governance: The case of Indonesia's forest management units in reducing emission from deforestation and forest degradation (REDD+). Society and Natural Resources, 27, 1346-1354.

Baccini, A., Goetz, S.J., Walker, W.S., Laporte, N.T., Sun, M., Sulla-Menashe, ... Houghton, R.A. (2012). Estimated carbon dioxide emissions from tropical deforestation improved by carbon-density maps. Nature Climate Change, 2, 182-185.

Barr, C.M., \& Sayer, J.A. (2012). The political economy of restoration and forest restoration in AsiaPacific: Critical issues for REDD+. Biological Conservation, 154, 9-19.

Brockhaus, M., di Gregorio, M., \& Mardiah, S. (2014). Governing the design of national REDD+: An analysis of the power of agency. Forest Policy and Economics, 49, 23-33.

Buntaine, M.T., \& Parks, B. C. (2013). When do environmentally focused assistance projects achieve their objectives? Global Environmental Politics, 13, 65-88.

Caplow, S. Jagger, P. Lawlor, K. \& Sills, E. (2011). Evaluating land use and livelihood impacts of early forest carbon projects: Lessons for learning about REDD+. Environmental Science and Policy, $14,152-167$.

DARD (Department of Agriculture and Rural Development, Lam Dong People Committee). (2014). Action plan on 'reduction of greenhouse gas emissions through efforts to reduce deforestation and forest degradation, sustainable management of forest resources, and conservation and enhancement of forest carbon stocks', in Lam Dong province, 2014-2020. Da Lat, Vietnam

FCPF, (2008). Forest Carbon Partnership Facility, Information Memorandum. Washington D.C. Retrieved from https://www.forestcarbonpartnership.org/sites/forestcarbonpartnership.org/files/FCPF_Info_Memo 06-13-08.pdf 
FCPF. (2009). Forest Carbon Partnership Facility, FY2009 Annual Report. Washington D.C. Retrieved from https://www.forestcarbonpartnership.org/sites/forestcarbonpartnership.org/files/Documents/PDF/De c2009/FCPF_FY09_Annual_Report_12-08-09.pdf

FCPF. (2012). Readiness preparation proposal. FCPF and UN-REDD. Washington D.C. Retrieved from https://www.forestcarbonpartnership.org/guidelines-and-templates

FCPF. (2011). Forest Carbon Partnership Facility, FY2011 Annual Report. Washington D.C. Retrieved from http://www.forestcarbonpartnership.org/sites/forestcarbonpartnership.org/files/Documents/PDF/Oct 2011/FCPF_Carbon_AR_FINAL 10 3.pdf

FCPF. (2015). Forest Carbon Partnership Facility, FY2015 Annual Report. Washington D.C. Retrieved from https://www.forestcarbonpartnership.org/sites/fcp/files/2015/November/FCPF\%20AR\%20FY15\%2 011\%204\%20\%28web\%29 0.pdf

FCPF. (2016a). Forest Carbon Partnership Facility, FY2016 Annual Report. Washington D.C. Retrieved from

https://www.forestcarbonpartnership.org/sites/fcp/files/2016/Sep/FCFP\%20Annual\%20Report\%20 FY16.pdf

FCPF. (2016b). REDD+ Annual country progress reporting, August 2014-August 2015. Jakarta, Indonesia. Retrieved from https://www.forestcarbonpartnership.org/sites/fcp/files/2016/Oct/230916_Final\%20NS_FCPF\%20 \%20Country\%20Progress\%20Report.pdf

FCPF. (2016c). Grant reporting and monitoring report, Vietnam readiness preparation proposal. Hanoi, Vietnam. Retrieved from https://www.forestcarbonpartnership.org/sites/fcp/files/2016/Sep/Vietnam_Approved\%20GRM 8\% 2024\%202016.pdf

FCPF. (2016d). Technical assessment of the final emission reduction program document (ER-PD) submitted by Vietnam on October $31^{\text {st }}$ 2016, Washington D.C. Retrieved from 
https://www.forestcarbonpartnership.org/sites/fcp/files/2016/Nov/Vietnam\%20Final\%20ERPD\%20--\%20TAP\%20Assessment\%20Nov\%2020\%202016.pdf

FCPF. (2017). Technical assessment of the final emission reduction program document (ER-PD) submitted by Vietnam on November 19 $19^{\text {th }}$ 2017, Washington D.C. Retrieved from https://www.forestcarbonpartnership.org/sites/fcp/files/2017/Nov/Vietnam\%20ERPD\%20TAP\%20Report\%20Dec\%201\%202017.pdf

FCPF. (2018). Resolution CFM/17/2018/2. Selection of emission reductions program document of Vietnam into the portfolio of the Carbon Fund of the FCPF. Retrieved from https://www.forestcarbonpartnership.org/sites/fcp/files/2018/January/Final\%20Resolution $\% 202 \% 2$ 0Vietnam\%20rev.pdf

Financial Times (2005). A solution to climate change in the world's rainforests, November 30

Fischer, R., Hargita, Y., \& Günter, S. (2016). Insights from the ground level? A content analysis review of multi-national REDD+ studies since 2010. Forest Policy and Economics, 66, 47-58.

Fletcher, R., Dressler, W., Büscher, B., \& Anderson, Z.R. (2016). Questioning REDD+ and the future of market-based conservation. Conservation Biology, 30, 673-675.

FORCLIME (Forests and Climate Change Programme), (2013). A comparison of the socio-economic vulnerability of forest ecosystem dependent villages in Kalimantan, Indonesia. GIZ, Jakarta.

Global Forest Watch, A partnership convened by World Resources Institute. Retrieved from http://www.globalforestwatch.org.

Hayes, T., \& Persha, L. (2010). Nesting local forestry initiatives: Revisiting community forest management in a REDD+ world. Forest Policy and Economics, 12, 545-553.

Howell, S. (2015). Politics of appearances: Some reasons why the UN-REDD project in central Sulawesi failed to unite the various stakeholders. Asia Pacific Viewpoint, 56, 37-47.

Howson, P., \& Kindon, S. (2015). Analysing access to the local REDD+ benefits of Sungai Lamandau, Central Kalimantan, Indonesia. Asia Pacific Viewpoint, 56, 96-110.

Jakarta Post, Indonesia to deal with the last part of One Map Policy, February 5, 2018 
JICA. 2015. Final technical workshop, Hanoi, 30-31 July

Kim, Y.S., Bae, J.S., Fisher, L.A., Latifah, S., Afifi, M., Lee, S.M. \& Kim, I.A. (2017). Indonesia's forest management units: Effective intermediaries in REDD+ implementation? Forest Policy and Economics, 62, 69-77.

Kunz, Y., Steinebach, S., Dittrich, C., Hauser-Schäublin, B., Rosyani, Ir., Soetarto, E., \& Faust, H. (2017). The fridge in the forest: Historical trajectories of land tenure regulations fostering landscape transformation in Jambi Province, Sumatra, Indonesia. Forest Policy and Economics, 81, 1-9.

Lederer, M., (2011). From CDM to REDD+ -- What do we know for setting up effective and legitimate carbon governance. Ecological Economics, 70, 1900-1907.

Lemos, M.C., \& Agrawal A. (2006). Environmental governance. Annu. Rev. Environ. Resourc., 31, 297-325.

Lund, J.F., Sungusia, E., Mabele, M.B., \& Sheba, A. (2016). Promising change, delivering continuity: REDD+ as conservation fad. World Development, 89, 124-139.

Matthews, R.B., van Noordwijk, M., Lambin, E., Meyfroidt, P., Gupta, J., Verchot, ... \& Veldkamp, E. (2014). Implementing REDD+ (Reducing Emissions from Deforestation and Degradation): evidence on governance, evaluation and impacts from the REDD-ALERT project. Mitigation Adaptation Strategies and Global Change, 19, 907-925.

Mitchell, A.L., Rosenquist, A. \& Mora, B. 2017. Current remote sensing approaches to monitoring forest degradation in support of countries measurement, reporting and verification (MRV) systems for REDD+. Carbon Balance and Management, 12, 9 Open access

https://cbmjournal.biomedcentral.com/track/pdf/10.1186/s13021-017-0078-9

Mbatu, R.S. (2016). REDD+ research: Reviewing the literature, limitations and ways forward. Forest Policy and Economics, 73, 140-152.

Miller, D.C. (2014). Explaining global patterns of international aid for linked biodiversity conservation and development. World Development, 59, 341-359 
Minang, P.A., van Noordwijk, M., Duguama, L.A., Alegemi, D., Alemagi D., Do T.H., ... Leimona, B. (2014). REDD+ Readiness progress across countries: time for reconsideration. Climate Policy, 14, 685-708.

Morin, J-F. \& Orsini, A. (eds.), (2013). Insights form Global Environmental Governance, International Studies Review, 15, 562-589.

NORAD. (2014). Real-time evaluation of Norway's international climate and forest initiative. Synthesising report 2007-2013. Report 3/2014. Retrieved from https://www.oecd.org/derec/norway/Real-Time-Evaluation-of-Norway-International-Climate-andForest-Initiative-Synthesising-Report-2007-2013.pdf

Norman M. \& Nakhooda S. (2014/2015): The state of REDD+ finance. CGD Working Paper 378, Washington DC: Center for Global Development (updated in May 2015). Retrieved from http://www.cgdev.org/sites/default/files/CGD-Norman-Nakhooda-Climate-Forests-5-REDD-

Finance.pdf

Ochieng, R.M., Visseren-Hamakers, I.J., Arts, B., Brockhaus, M., \& Herold, M. (2016). Institutional effectiveness of REDD+ MRV: Countries progress in implementing technical guidelines and good governance requirements. Environmental Science \& Policy, 61, 42-52.

Pattberg, P., \& Widerberg, O. (2015). Theorising global environmental governance: Key findings and future questions. Millennium, 43, 684-705.

P3SEKPI. (2017). REDD+Readiness Self-Assessment for Indonesia submitted to the Forest Carbon Partnership Facility (FCPF). Center for Research and Development on Social, Economy, Policy and Climate Change, Forestry Research, Development, and Innovation Agency, Ministry of Environment and Forestry, Republic of Indonesia.

Purnomo, H., Suyamto, D., Abdullah, L. \& Irawati, R.H. 2012. REDD+ actor analysis and politicial mapping: an Indonesian case study. International Forestry Review, 14, 74-89.

Republic of Indonesia. (2014). Updated mid-term progress report of the Republic of Indonesia. Jakarta. from 
https://www.forestcarbonpartnership.org/sites/fcp/files/2014/May/Mid\%20Term\%20progress\%20R eport\%20Indonesia\%20May\%202014_0.pdf

Republic of Indonesia. (2015/2016). Emission Reductions Program Idea Note. Jakarta, Indonesia. Retrieved from https://www.forestcarbonpartnership.org/sites/fcp/files/2016/May/Indonesian\%20ERPIN\%2020160429\%20Final.pdf

Republic of Indonesia. (2016). First Nationally Determined Contribution. Jakarta. Retrieved from http://www4.unfccc.int/ndcregistry/PublishedDocuments/Indonesia\%20First/First\%20NDC\%20Ind onesia_submitted $\% 20$ to $\% 20$ UNFCCC $\% 20$ Set_November $\% 20 \% 202016 . p d f$

Republic of Indonesia. (2018). Emission Reductions Program Document (ER-PD). Jakarta, Indonesia.

https://www.forestcarbonpartnership.org/sites/fcp/files/Indonesia_FCPFRF\%202018\%20Report\%20DRAFT\%20.pdf

Republic of Vietnam. (2012). Decision on approval of the national action program on reduction of green-house gas emissions through efforts to reduce deforestation and forest degradation, Hanoi, Vietnam, No. 799/QD-TTg

Republic of Vietnam. (2016a). Emission Reductions Program Document (ER-PD). Ministry of Agriculture and Rural Development. Hanoi. Retrieved from https://www.forestcarbonpartnership.org/sites/fcp/files/2016/Nov/Vietnam\%20Final\%20ERPD\%20\%20Oct\%2031\%20\%28rev\%29\%20for\%20CF15.pdf

Republic of Vietnam. (2016b). Intended Nationally Determined contribution of Viet Nam, Hanoi. Retrieved from

http://www4.unfccc.int/ndcregistry/PublishedDocuments/Viet\%20Nam\%20First/VIETNAM\%27S \%20INDC.pdf

Republic of Vietnam, Ministry of Agriculture and Rural Development. (2018). Emission Reductions Program Document (ER-PD)- January, 2018, FCPF. Retrieved from https://www.forestcarbonpartnership.org/sites/fcp/files/2018/January/00_FINAL\%20ERPD\%20Vietnam\%205\%20Jan\%202018_.pdf 
Resosudarmo, I.A.P, Atmadja, S., Ekaputri, A.D., Intarini, D.Y., \& Indriatmoko, Y. (2014). Does tenure security lead to REDD+ project effectiveness?: Reflections form five emerging sites in Indonesia. World Development, 55, 68-83,

Robiglio, V., Armas, A.D., Silva Aguad, C., White, D. 2014. Beyond REDD+ readiness: land-use governance to reduce deforestation in Peru, Climate Policy, 14, 734-747

Streck, C. 2012. Financing REDD+: matching needs and ends. Current Opinion in Environmental Sustainability, 4, 628-637

Sunderlin, W.D., Larson, A.M., Duchelle, A.E., Resosudarmo, I.A., Huynh, T.B., Awono, A., \& Dokken, T. (2014). How are REDD+ proponents addressing tenure problems? Evidence from Brazil, Cameroon, Tanzania, Indonesia and Vietnam, World Development, 55, 37-52.

Svarstad, H \& Benjaminsen, T.A. 2017. Nothing succeeds like success narratives: a case of conservation and development in the time of REDD. Journal of Eastern African Studies, 11, 482-505

Taylor, P.L., \& Cheng, A.S. (2012). Environmental governance as embedded process: Managing change in two community-based forestry organizations. Human Organization, 71, 110-122.

FCPF

UNFCC. (2007). Report of the Conference of the Parties on its thirteenth session, held in Bali from 3 to 15 December 2007. Retrieved from http://unfccc.int/resource/docs/2007/cop13/eng/06a01.pdf

UNFCC (2010). Report of the Conference of the Parties on its fifteenth session, held in Copenhagen from 7 to 19 December 2009. Retrieved from

https://unfccc.int/sites/default/files/resource/docs/2009/cop15/eng/11.pdf

UNFCC. (2011). Report of the Conference of the Parties on it sixteenth session, held in Cancun from 29 November to 10 December 2010. Retrieved from http://unfccc.int/resource/docs/2010/cop16/eng/07a01.pdf

UNFCC. (2015). Report of the Conference of the Parties on its twenty-first session, held in Paris from 30 November to 13 December 2015. Retrieved from http://unfccc.int/resource/docs/2015/cop21/eng/10a01.pdf 
UN-REDD. (2008). UN-REDD Framework Document. New York. Retrieved from http://earthpeoples.org/blog/wp-content/uploads/2008/11/un-redd fund annex-a-framework.pdf

UN-REDD. (2009a). Indonesia UN-REDD national joint programme. Jakarta, Indonesia. Retrieved from http://www.unredd.net/documents/un-redd-partner-countries-181/asia-the-pacific-333/a-ppartner-countries/indonesia-187/national-programme-submission-and-approval-1548/nationalprogramme-documents-1707/3276-indonesia-signed-national-programme-document-3276.html

UN-REDD. (2010). UN-REDD Programme annual progress report 2009. New York. Retrieved from http://www.unredd.net/documents/programme-progress-reports-785/2009-3237.html

UN-REDD. (2012). Lessons learned- Vietnam UN-REDD programme, Phase 1. Retrieved from http://theredddesk.org/resources/lessons-learned-viet-nam-un-redd-programme-phase-1

UN-REDD. (2013). UN-REDD Vietnam Phase II Programme: Operationalising REDD+ in Vietnam. Hanoi. Retrieved from http://vietnam-redd.org/Upload/CMS/Content/REDD\%20projects/UNREDD\%20VN\%20Phase\%202/PD-signed.pdf

Walker, B., Barett, S., Polasky, S, Galaz, V., Folke, C., Engström, G... \& de Zeeuw, A. (2009). Looming global-scale failures and missing institutions, Nature, 325, 1345- 1346

White, D. 2014. A perfect storm? Indigenous rights within a national REDD+ readiness process in Peru, Mitigation \& Adaptation Strategies for Global Change, 19: 657-676

Wibowo, A. \& Giessen, L. (2015). Absolute and relative power gains among state agencies in forestrelated land use policies: The Ministry of Forest and its competitors in the REDD+ programme and the One Map Policy in Indonesia, Land Use Policy, 49, 131-141 